\title{
Carbon fluxes in coral reefs. II. Eulerian study of inorganic carbon dynamics and measurement of air-sea $\mathrm{CO}_{2}$ exchanges
}

\author{
Michel Frankignoulle ${ }^{1, * * * *}$, Jean-Pierre Gattuso ${ }^{2,3}$, Renzo Biondo ${ }^{1}$, \\ Isabelle Bourge ${ }^{1, * *}$, Gérard Copin-Montégut ${ }^{4}$, Michel Pichon ${ }^{3,5,6}$ \\ 'Laboratoire d'Océanologie, Université de Liège, Institut de Chimie Bât B6, B-4000 Sart Tilman, Belgium \\ ${ }^{2}$ Observatoire Océanologique Européen, Centre Scientifique de Monaco, Avenue Saint-Martin, MC-98000 Monaco, \\ Principality of Monaco \\ ${ }^{3}$ Laboratoire de Biologie Marine et Malacologie, URA CNRS 1453, EPHE, Université de Perpignan, F-66860 Perpignan Cedex, France \\ ${ }^{4}$ Observatoire Océanologique, Université Pierre et Marie Curie, BP 8, F-06230 Villefranche-sur-mer Cedex, France \\ ${ }^{5}$ Australian Institute of Marine Science, PMB No. 3, Townsville M. C., Queensland 4810, Australia \\ ${ }^{6}$ Centre de Recherches Insulaires et Observatoire de l'Environnement, EPHE, BP 1013, Moorea, French Polynesia
}

\begin{abstract}
Air-sea $\mathrm{CO}_{2}$ exchanges and the partial pressure of $\mathrm{CO}_{2}$ were measured in surface water overlying 2 coral reefs: Moorea (French Polynesia, austral winter, August 1992), where coral diversity and surface cover are low, and Yonge Reef (Great Barrier Reef, austral summer, December 1993), where coral diversity and cover are comparatively higher A procedure is proposed to estimate the potential $\mathrm{CO}_{2}$ exchange with the atmosphere by taking into account both the saturation level of oceanic seawater and the equilibration process occurring after water leaves the reef. It is shown that both sites were net sources of $\mathrm{CO}_{2}$ to the atmosphere as a result of the effect of calcification on the dynamics of the inorganic carbon system. The potential global $\mathrm{CO}_{2}$ evasion from the ocean to the atmosphere is about 4 times higher at Yonge Reef than at Moorea. It is also demonstrated that, at both sites, the major exchange of $\mathrm{CO}_{2}$ from sea to air occurs as seawater returns to chemical equilibrium after it has crossed and left the reef. The dynamics of inorganic carbon were studied using the so-called homogeneous buffer factor $\beta=d \ln \left(\mathrm{pCO}_{2}\right) / \mathrm{d} \ln (\mathrm{DIC})$ ( where $\mathrm{pCO}_{2}$ is the $\mathrm{CO}_{2}$ partial pressure in surface water and $\mathrm{DIC}$ is dissolved inorganic carbon), which gave estimates that approximately $80 \%$ of the change in inorganic carbon was related to photosynthesis and respiration. This approach showed that the calcification rate was proportional to the net organic production during the day and to the respiration rate at night.
\end{abstract}

KEY WORDS: Coral reefs Inorganic carbon Arr-sea $\mathrm{CO}_{2}$ exchanges

\section{INTRODUCTION}

It is not yet certain how much and how quickly excess atmospheric $\mathrm{CO}_{2}$ is taken up by the oceans (see e.g. Tans et al. 1990, Watson et al. 1991). While the open orean is close to atmospheric $\mathrm{CO}_{2}$ equilibrium, the situation in coastal areas is far less certain because

\footnotetext{
-E-mail: michel.frankignoulle@ulg.ac.be

- Present address: Université de Liège, Mécanique des Fluides Géophysiques, Unité d'Océanographie Chimique, Institut de Physique (B5), B-4000 Sart Tilman, Belgium
}

data are so far very sparse. Coastal areas are sites of intense primary production and specific processes (upwelling, river input) which can induce strong variations of dissolved inorganic carbon and associated high air-sea $\mathrm{CO}_{2}$ fluxes (Mackenzie et al. 1991, Wollast 1991). Air-sea $\mathrm{CO}_{2}$ exchange in coastal areas is thus a fundamental process which could play a significant role in the global carbon cycle.

Coral reefs are important shallow-water, tropical ecosystems due to their geographical extent $\left(617000 \mathrm{~km}^{2}\right.$, i.e. $15 \%$ of the sea floor surface area between 0 and $30 \mathrm{~m}$; Smith 1978). In terms of carbon dynamics, 2 
important biological processes occur in these ecosystems: metabolism of organic carbon (photosynthesis and respiration) and metabolism of inorganic carbon (precipitation and dissolution of calcium carbonate).

In the context of the atmospheric carbon budget, marine calcification can have important consequences because this process is known to release dissolved $\mathrm{CO}_{2}$ to the surrounding water and can then act as a net source of $\mathrm{CO}_{2}$ to the atmosphere., Ware et al. (1992) have demonstrated, using numerical calculations, that $0.6 \mathrm{~mol} \mathrm{CO}_{2}$ is released in surrounding water for each mole of calcium carbonate precipitated. More recently, Frankignoulle et al. (1994) have shown that the released $\mathrm{CO}_{2}$ /precipitated $\mathrm{CaCO}_{3}$ ratio reflects a positive feedback to the increasing atmospheric $\mathrm{CO}_{2}$ and it increases from 0.6 (at present atmospheric $\mathrm{CO}_{2}$ level) to 0.84 when the $\mathrm{CO}_{2}$ partial pressure in surface water $\left(\mathrm{pCO}_{2}\right)=1000$ ratm. Since coral reefs are characterized by a net organic production close to zero (Kinsey 1983), calcification could play a major role in atmospheric exchange of $\mathrm{CO}_{2}$ in coral reefs

The evidence for $\mathrm{CO}_{2}$ release to the atmosphere in coral reefs has recently been demonstrated by Gattuso et al. (1993), who carried out the first field measurements of air-sea $\mathrm{CO}_{2}$ exchanges on a coral reef flat (Moorea, French Polynesia, summer 1991). During $24 \mathrm{~h}$ experiments, they observed daily variations of the flux direction in agreement with the photosynthesis/ respiration cycle: $\mathrm{CO}_{2}$ uptake during the day and $\mathrm{CO}_{2}$ release at night. They found that over $24 \mathrm{~h}$ the net $\mathrm{CO}_{2}$ flux from sea to air was approximately $1.5 \mathrm{mmol} \mathrm{CO}_{2}$ $\mathrm{m}^{-2}$. More recently, Kayanne et al. (1995) monitored daily changes in dissolved $\mathrm{CO}_{2}$ over a sub-tropical reef (Shiraho reef, Ryukyu Islands, Japan) and concluded that reefs could behave as sinks for atmospheric $\mathrm{CO}_{2}$. Their conclusion that all reefs may behave as sinks for $\mathrm{CO}_{2}$ has been questioned (Buddemeier 1996, Gattuso et al. 1996) for several reasons, but mainly because their study site is not representative of the 'standard' reef system as described by Kinsey (1983) and does not allow such generalisation.

This paper presents data related to daily changes of inorganic carbon and air-sea $\mathrm{CO}_{2}$ fluxes measured at a single back reef station (Eulerian approach). The objectives of this work are (1) to complement observations previously made at Moorea during austral winter, (2) to compare results obtained in a reef subject to relatively intense anthropogenic stresses (Moorea) with a pristine reef (Yonge Reef, Great Barrier Reef, Australia), (3) to discuss the respective influence of processes which drive air-sea $\mathrm{CO} 2$ fluxes over the reef flat (i.e. mainly initial seawater conditions, metabolic and physical effects), (4) to estimate the overall metabolism effect on atmospheric $\mathrm{CO}_{2}$ budget and to compare it with air-sea flux data measured over the reef itself, and (5) to use inorganic carbon thermodynamical equations to estimate the ratio of organic to inorganic metabolisms from this Eulerian approach.

\section{MATERIAL AND METHODS}

Data presented here were obtained during 2 field trips, one at Moorea (Tiahura Barrier Reef, JulyAugust 1992) and the other at Yonge Reef (December 1993). Community structure and composition of both sites are well known. Information regarding the study sites is given in a companion paper (Gattuso et al. 1996 in this issue).

To assess the effect of reef metabolism on air-sea exchange of $\mathrm{CO}_{2}$, measurements of inorganic carbon and related parameters were carried out over three $24 \mathrm{~h}$ periods at a back reef station at each site. Discrete seawater samples were taken at oceanic stations. The current patterns across the reefs were relatively simple: water moved from the ocean across the reef and its velocity was modulated by tide. Back reef stations are therefore ideal sites at which to study the effect of reef metabolism on oceanic seawater.

The sampling protocol involved measurements of air-sea $\mathrm{CO}_{2}$ exchange, determination of $\mathrm{CO}_{2}$ partial pressure in surface water (indirect method), as well as hydrological and meteorological parameters (salinity. water temperature, tide, atmospheric pressure, solar radiation, wind speed and air temperature).

$\mathrm{pCO}_{2}$ was calculated from measurements of $\mathrm{pH}$ and total alkalinity (TA). At both sites, total alkalinity was sampled each hour and measured using the classical Gran electrotitration method (Gattuso et al. 1993). pH was measured using commercial combination electrodes, but sampling intervals and procedures were different between Moorea and Yonge Reef. At Moorea, the electrode (Radiometer, GK2401C) was installed on an in situ data-logger and measurements were carried out each half hour at seawater tempera. ture (Gattuso et al. 1996). Calibration was made using National Bureau of Standards (NBS) standards and reproducibility was $\mathrm{pH} 0.007$.

At Yonge Reef, the $\mathrm{pH}$ electrode (Ross type, Orion) was installed aboard the research vessel in a cell continuously thermoregulated with surface seawater A computerized interface was used to carry out 1 measurement every minute. Correction to in situ temperature from the cell temperature $\left(0.1\right.$ to $\left.0.5^{\circ} \mathrm{C}\right)$ was made according to Perez \& Fraga (1987). The Ross-type electrode was calibrated using Tris buffer, as proposed by Dickson (1993), on the total proton scale [pH(Seawater scale, SWS)I. The reproducibility of $\mathrm{pH}$ measurement was $\pm 0.2 \mathrm{mV}$, which corresponds to an error of $\mathrm{pH}$ 0.004 . 
$\mathrm{pCO}_{2}$ and the $\mathrm{CO}_{2}$ speciation were calculated according to the $\mathrm{pH}$ (SWS) scale (total proton, mol $\mathrm{kg}^{-1}$ ) using the $\mathrm{CO}_{2}$ acidity constants of Goyet \& Poisson (1989), the $\mathrm{CO}_{2}$ solubility coefficient of Weiss (1974) and the borate acidity constant of Hansson (1973). The total borate molality was calculated using the Culkin (1965) ratio to salinity. The error in $\mathrm{pCO}_{2}$, calculated from errors in $\mathrm{pH}$ and TA, was about $2 \%(6 \mu$ atm when $\left.\mathrm{pCO}_{2}=350 \mu \mathrm{atm}\right)$. When $\mathrm{pH}$ was calibrated using NBS standards, $\mathrm{CO}_{2}$ dissociation constants of Mehrbach et al. (1973) were used and the error in $\mathrm{pCO}_{2}$ was estimated to be about $3 \%$ ( 8 to 10 hatm when $\mathrm{pCO}_{2}=$ 350 uatm).

Dissolved oxygen was determined in each site at the same frequency as $\mathrm{pH}$ (i.e. every half hour at Moorea and every minute at Yonge Reef) using a galvanic electrode (Kent Eil) at Moorea and a polarographic electrode (Orbisphere) at Yonge Reef. Sensors were calibrated against air-saturated seawater and a sodium dithionite solution as zero. Saturation oxygen levels were calculated according to the algorithm of Benson \& Krause (1984).

Solar radiation was measured continuously (every minute) using a LI-COR (LI-192SA) quantum sensor which integrates light from 400 to $700 \mathrm{~nm}$ and yields data expressed in $\mu \mathrm{mol}$ photons $\mathrm{m}^{-2} \mathrm{~s}^{-1}$. Tides at Moorea were calculated using the simplified harmonic method (SHM package) and harmonic coefficients of Matavaï (Tahiti) from Admiralty Charts Tables. Wind speed was measured using a hand anemometer On the Great Barrier Reef, tide and meteorological parameters (wind speed, air and water temperatures, atmospheric pressure) were monitored (10 min) using a WLR 5 and a weather station (Aanderaa Instruments) respectively.

Air-sea $\mathrm{CO}_{2}$ exchanges were measured using the bell method described by Frankignoulle (1988). This method involves the deployment of a closed incubator on the sea surface and the detection of initial (10 min) $\mathrm{CO}_{2}$ variations in the gas phase with a LI-COR 6252 infra-red gas analyser. The analyser was calibrated using pure nitrogen (zero) and a commercial standard for $\mathrm{CO}_{2}(350 \pm 3 \mu \mathrm{atm})$. The infrared analyser was also used to measure the atmospheric partial pressure of $\mathrm{CO}_{2}$. As far as possible, measurements were carried out every half hour at both sites. The exchange coefficient was calculated using Henry's law:

$$
F=K \alpha \Delta \mathrm{PCO}_{2}
$$

where $F$ is the flux (in $\mathrm{mol} \mathrm{m} \mathrm{m}^{-2} \mathrm{~s}^{-1}$ ), $K$ is the exchange coefficient (in $\mathrm{m} \mathrm{s}^{-1}$ ), $\alpha$ is the $\mathrm{CO}_{2}$ solubility coefficient (in $\mathrm{mol} \mathrm{m} \mathrm{m}^{-3} \mathrm{~atm}^{-1}$ ) and $\triangle P \mathrm{CO}_{2}$ is the $\mathrm{CO}_{2}$ gradient through the air-sea interface (water-air, in atm).

The dynamics of inorganic carbon were studied in terms of the so-called homogeneous buffer factor $\beta$ (see Sundquist \& Plummer 1981), which is a convenient parameter for discussion of which process is responsible for inorganic carbon variations:

$$
\beta=\left(\frac{\Delta \mathrm{pCO}_{2}}{\mathrm{pCO}_{2}}\right)\left(\frac{\Delta \mathrm{DIC}}{\mathrm{DIC}}\right)^{-1}=\frac{\mathrm{d} \ln \left(\mathrm{pCO}_{2}\right)}{\mathrm{d} \ln (\mathrm{DIC})}
$$

The homogeneous buffer factor $\beta$ can be obtained from a data set by plotting $\ln \left(\mathrm{pCO}_{2}\right)$ versus $\ln (\mathrm{DIC})$ When dissolved $\mathrm{CO}_{2}$ is the inorganic species involved in the carbon exchange (e.g. air-sea exchange), this buffer factor is the so-called Revelle factor and its value is about 12 for average seawater conditions. The factor can be significantly different from 12 if processes other than uptake or release of dissolved $\mathrm{CO}_{2}$ occur. Frankignoulle (1994) recently proposed a relationship which allows calculation of $\beta$ when organic and inorganic carbon metabolisms occur simultaneously $\left(\mathrm{r}^{2}=\right.$ $0.9994, p<0.0000)$ :

$$
\beta=-7.02+0.186 \times \mathrm{C}_{\text {org }}
$$

where $\% \mathrm{C}_{\text {org }}$ is the percentage of change in inorganic carbon concentration due to organic metabolism (photosynthesis and respiration). This equation was obtained by taking into account both $\mathrm{CO}_{2}$ and $\mathrm{H}_{3} \mathrm{O}^{+}$ uptake as suggested by Redfield et al. (1963). The buffer factor displays a wide range of values depending on the inorganic species involved in the $\mathrm{CO}_{2}$ dynamics. It ranges from -7 (only carbonate change, $\left.\% \mathrm{C}_{\text {org }}=0\right)$ to $+12\left(\% \mathrm{C}_{\text {org }}=100\right)$.

\section{RESULTS}

\section{Moorea (austral winter)}

Fig 1 shows air-sea $\mathrm{CO}_{2}$ fluxes, $\mathrm{pCO}_{2}$, water temperature, irradiance, tide and oxygen saturation obtained over 3 diel cycles at Moorea during July and August. 1992.

As already mentioned by Gattuso et al. (1993), airsea $\mathrm{CO}_{2}$ fluxes displayed strong daily variations with $\mathrm{CO}_{2}$ invasion during the day and $\mathrm{CO}_{2}$ evasion at night. Measurements of daily variations in $\mathrm{pCO}_{2}$ showed that (1) $\mathrm{pCO}_{2}$ changed from about $240 \mu$ atm during the day to $400 \mu \mathrm{atm}$ at night, in good agreement with metabolic processes (superimposition of diurnal photosynthetic $\mathrm{CO}_{2}$ uptake and the production of dissolved $\mathrm{CO}_{2}$ by respiration and calcification) and (2) the shift of the direction of air-sea $\mathrm{CO}_{2}$ fluxes was in perfect agreement with that of the sign of the $\mathrm{CO}_{2}$ gradient through the interface which drives the fluxes (Eq. 1).

Dissolved $\mathrm{O}_{2}$ varied inversely with $\mathrm{pCO}_{2}$ and corresponded closely with related metabolic processes, displaying strong over-saturation during the day (up to $160 \%$ ) and under-saturation at night. Tidal range was 

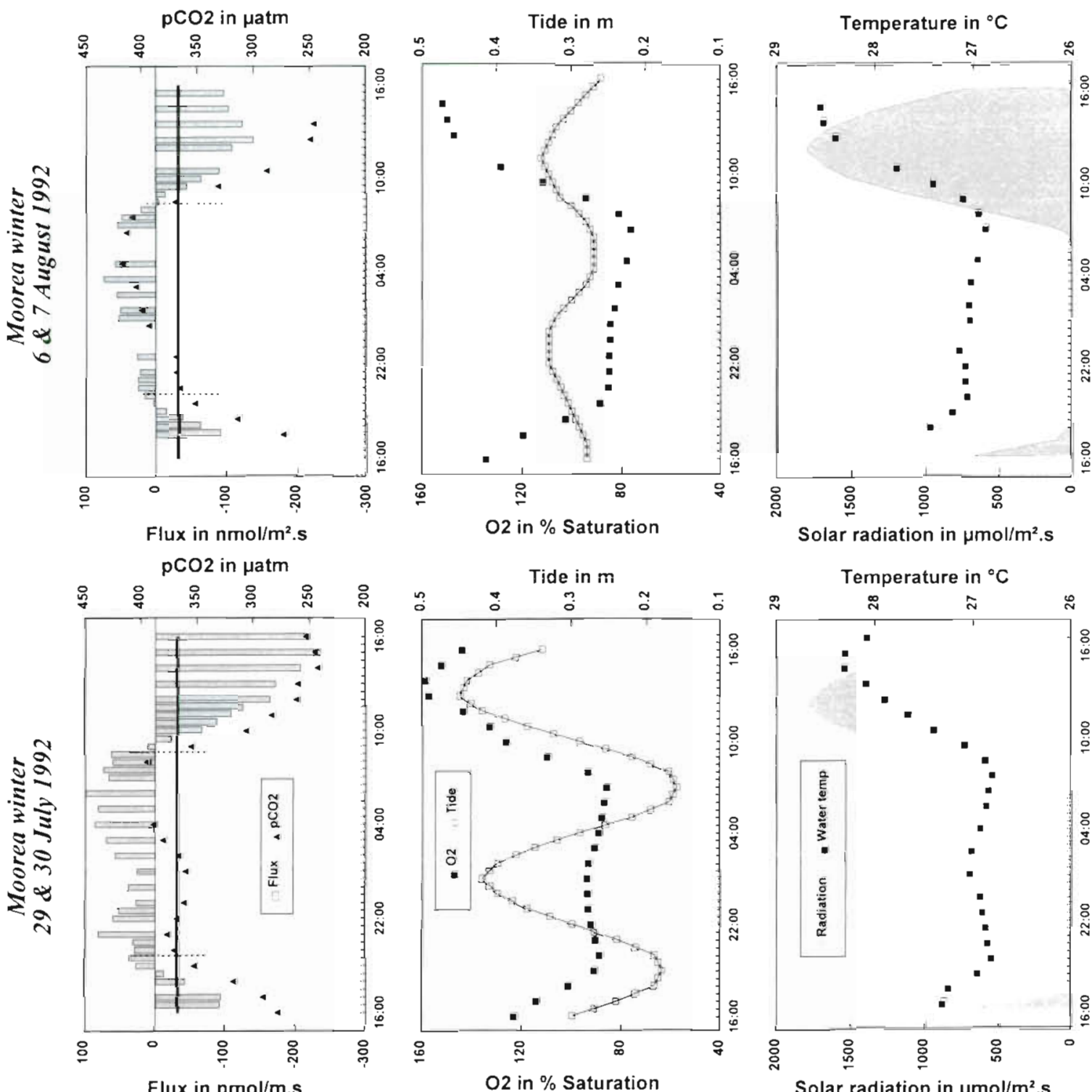

Flux in nmol/m.s

pCO2 in ratm
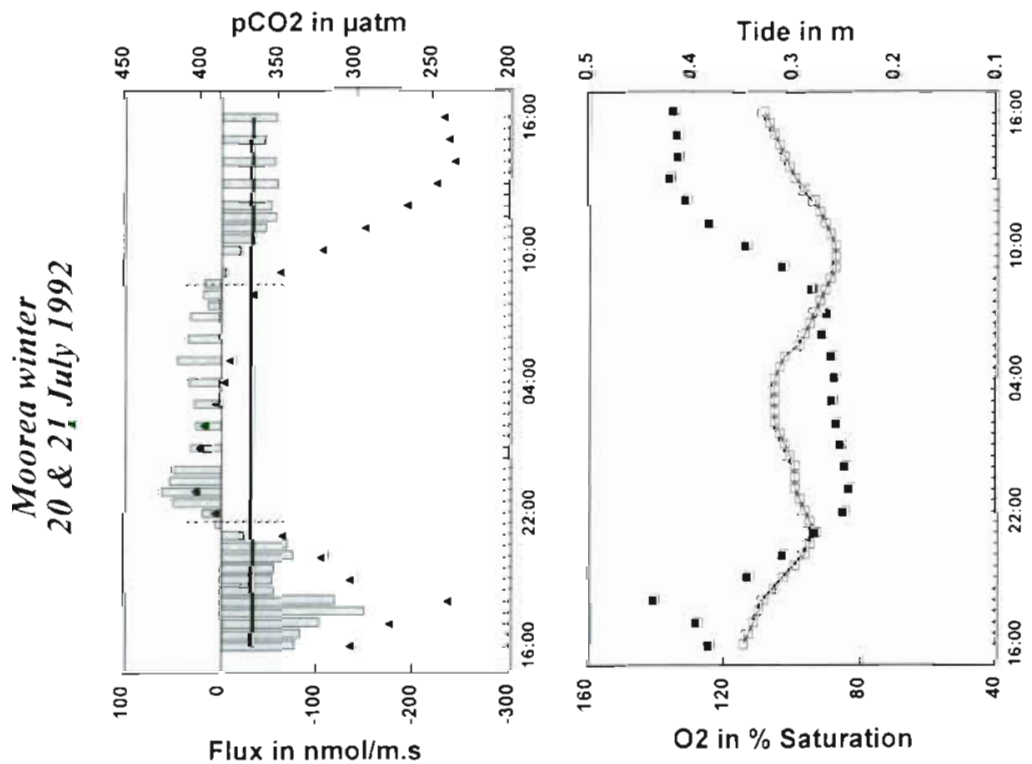

Solar radiation in $\mu \mathrm{mol} / \mathrm{m}^{2}$.s

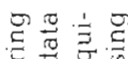

$\exists$ \&

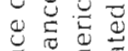

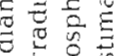

D $=$ ह क

$\exists$ 过范告

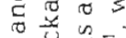

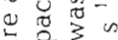

$\overline{0} 0^{N} E$

更证。

द्ध 용

प्ठे

30

$\stackrel{0}{0}$

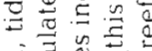

उ)

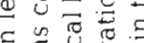

일 3

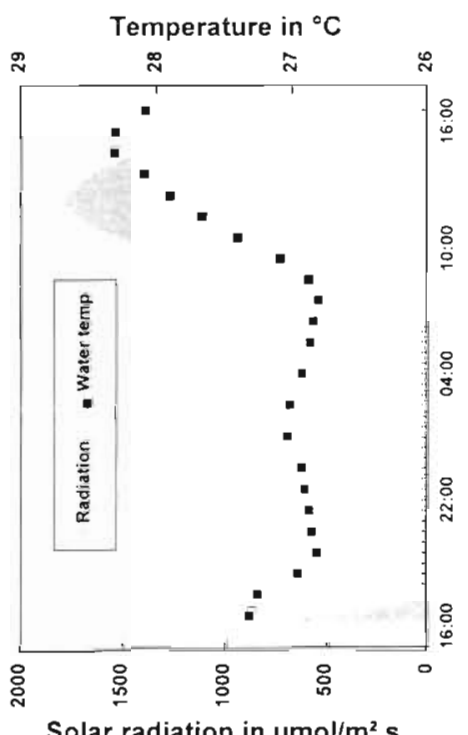

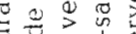

is 0

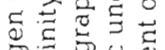

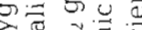

×

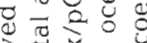

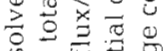

记志志

Q

施至

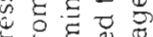

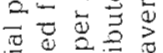

苋芯志要

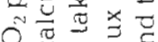

$0 \cup \vec{a}$

药

0,0

U क क

$5 \approx \Xi$

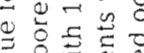

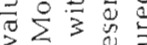

o $\overrightarrow{0} 0$

$\Xi \circlearrowleft$

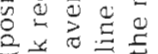

政元

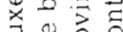

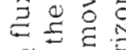

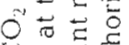

\%

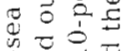

它氙导

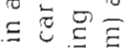

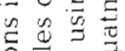

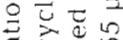

己气

$>$ 可

它氖氙 
quite small at Moorea and the maximum signal was approximately $30 \mathrm{~cm}$ during the second cycle. Water temperature ranged between 27 and $28.5^{\circ} \mathrm{C}$ and its variation was driven by solar radiation.

\section{Yonge Reef (austral summer)}

Fig. 2 shows the results obtained at Yonge Reef in December 1993. The partial pressure of $\mathrm{CO}_{2}$, air-sea $\mathrm{CO}_{2}$ fluxes and dissolved oxygen displayed changes similar to those observed at Moorea. At this site, both $\mathrm{pCO}_{2}$ and air-sea flux variations were high, with values ranging from 250 to $700 \mu \mathrm{atm}$ and from -250 to $+700 \mathrm{nmol} \mathrm{m} \mathrm{m}^{-2} \mathrm{~s}^{-1}$ respectively. Tide appeared to be an important forcing process at Yonge Reef, with a semidiurnal signal of $3.5 \mathrm{~m}$ during the third cycle. The highest flux and $\mathrm{pCO}_{2}$ observed values were recorded during the nocturnal low tide period. Water temperature variations, ranging from 26 to $28.5^{\circ} \mathrm{C}$, were driven by both tide and solar radiation with minima associated with nocturnal low tide and maxima associated with maximal incoming radiation.

\section{Daily atmospheric budgets at the back reef}

Daily integration of air-sea $\mathrm{CO}_{2}$ fluxes measured at the back reefs and shown in Figs. 1 \& 2 was carried out for both sites (Table 1). As already suggested by flux patterns in Fig 1, the Moorea winter computation yields negative values $\left(\mathrm{CO}_{2}\right.$ invasion), whereas positive values were found at Moorea and at Yonge Reef in summer ( $\mathrm{CO}_{2}$ evasion). There is a major difference in oceanic $\mathrm{pCO}_{2}$ between sites and seasons: the oceanic surface water was in equilibrium with the atmosphere at Moorea in summer and at Yonge Reef $\left(\mathrm{pCO}_{2} \approx\right.$ $350 \mu \mathrm{atm}$ ), whereas it was under-saturated at Moorea in winter $\left(\mathrm{pCO}_{2} \approx 326 \mathrm{~atm}\right)$.

\section{DISCUSSION}

\section{Potential budgets of air-sea $\mathrm{CO}_{2}$ fluxes}

Th seasonal change observed at Moorea in the surface oceanic water is due to a temperature effect and is in good agreement with $\mathrm{pCO}_{2}$ measurements carried out in French Polynesia by Y. Dandonneau (pers. comm.). The oceanic water at Moorea in winter was therefore a sink for atmospheric $\mathrm{CO}_{2}$ before it reached the reef. This initial condition has to be taken into account to estimate the net effect of reef metabolism on the air-sea $\mathrm{CO}_{2}$ flux budget. A simple procedure enables one to take into account the fact that oceanic
Table 1 Daily integration of measured air-sea $\mathrm{CO}_{2}$ fluxes (positive values for evasion) at the back of the reef (S: summer, W: winter). The single value for Moorea summer is from Gattuso et al. (1993)

\begin{tabular}{|c|c|c|c|}
\hline & \multicolumn{3}{|c|}{ Daily atmospheric $\mathrm{CO}_{2}$ fluxes $\left(\mathrm{mmol} \mathrm{m} \mathrm{m}^{-2} \mathrm{~d}^{-1}\right.$} \\
\hline & Moorea S & Moorea W & Yonge Reef $\mathrm{S}$ \\
\hline Diel 1 & +1.5 & -1.2 & +2.7 \\
\hline Diel 2 & - & -2.1 & +6.5 \\
\hline Diel 3 & - & -1.1 & +3.2 \\
\hline
\end{tabular}

water impinging on the reef is not always in equilibrium with the atmosphere. It also takes into account the fact that air-sea $\mathrm{CO}_{2}$ exchange is a slow process which continues after the water mass has left the reef system.

The procedure can be summarized as follows (see also Fig. 3): (1) Oceanic conditions (pH, TA, salinity and temperature) are used to calculate the total dissolved inorganic carbon concentration (DIC). Assuming constant $\mathrm{TA}$, the oceanic $\mathrm{pCO}_{2}$ is set to $355 \mu \mathrm{atm}$ in order to derive the DIC concentration corresponding to atmospheric equilibrium. The difference between these DIC values is the amount of $\mathrm{CO}_{2}$ that has to be exchanged with the atmosphere to restore atmospheric equilibrium $\left(\Delta \mathrm{DlC} \mathrm{C}_{\mathrm{D}}\right)$. (2) The same procedure is applied at the back reef and yields $\triangle \mathrm{DIC}_{\mathrm{br}}$. At the back reef, where DIC displays daily changes, $\triangle \mathrm{DIC}_{\mathrm{br}}$ is calculated every hour and is then integrated over $24 \mathrm{~h}$. (3) The difference $\triangle \mathrm{DIC}_{\mathrm{br}}-\triangle \mathrm{DIC}$ is the potential atmospheric $\mathrm{CO}_{2}$ flux resulting from the effect of reef metabolism. (4) To obtain the total reef effect, it is necessary to take into account air-sea fluxes occurring on the reef flat itself (i.e. before the water reaches the back reef station). These are not included in the above calculation. Fluxes over the reef flat can be estimated from air-sea $\mathrm{CO}_{2}$ fluxes measured at the back reef by integration over the water column, which is a good estimation because the water column is shallow and well-mixed.

Results are called 'potential air-sea $\mathrm{CO}_{2}$ fluxes' because they assume that the water mass goes back to atmospheric equilibrium after crossing the reef. This procedure enables estimation of the reef effect in terms of $\mathrm{CO}_{2}$ thermodynamics in seawater. The potential air-sea $\mathrm{CO}_{2}$ fluxes obtained for both sites are shown in Table 2.

We conclude that (1) at Moorea in winter, the

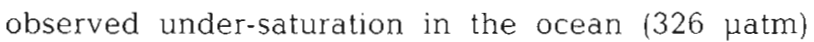
induces an oceanic air-sea $\mathrm{CO}_{2}$ flux that corresponds to an invasion of $20 \mu \mathrm{mol} \mathrm{kg}^{-1}$ to reach equilibrium. Since oceanic water was at equilibrium in front of Yonge Reef, the corresponding $\triangle \mathrm{DIC}_{0}$ is zero, (2) at Moorea in winter, a smaller air-sea $\mathrm{CO}_{2}$ flux was necessary to equilibrate the system at the back reef than 

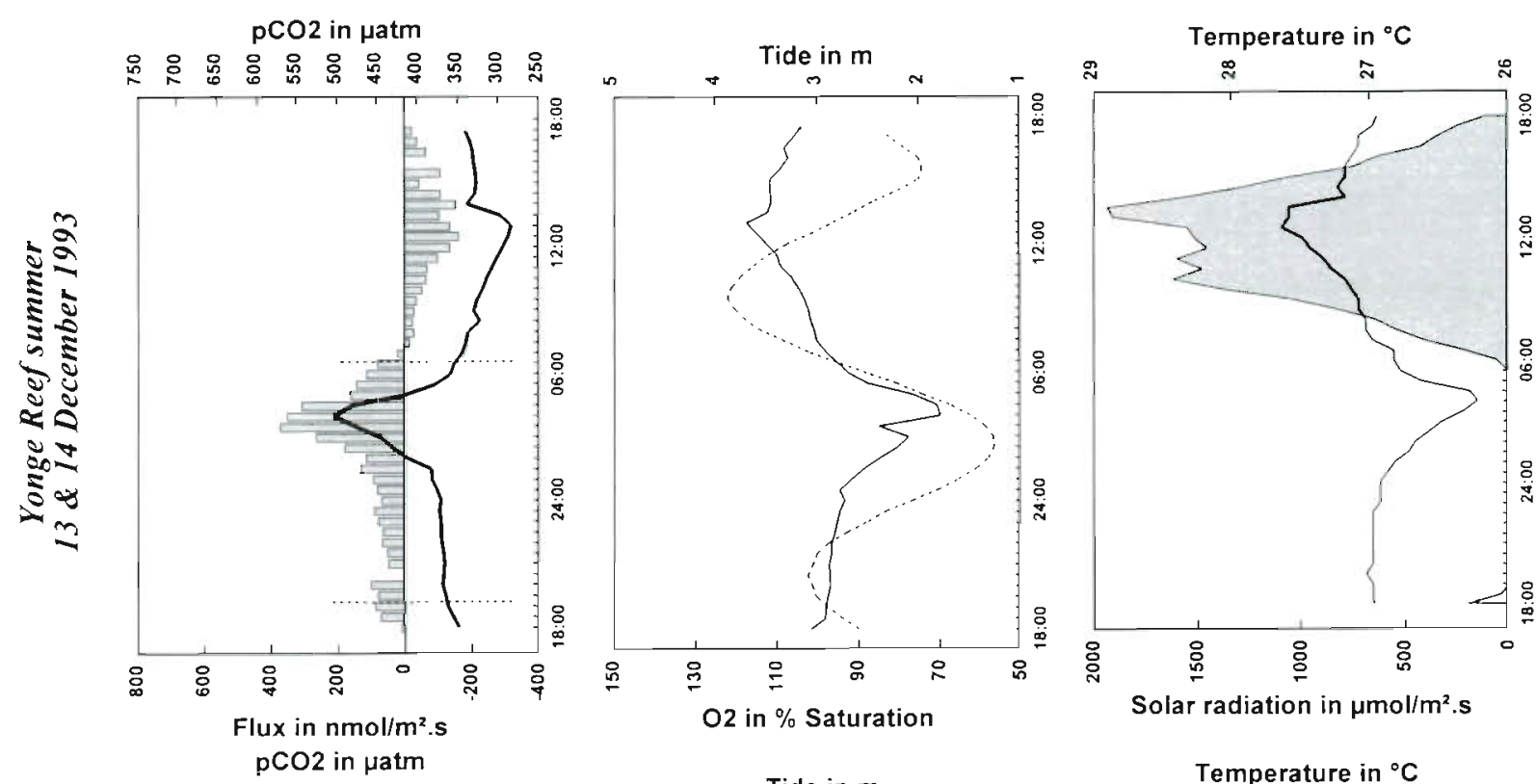

志祘㤩

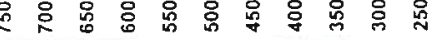

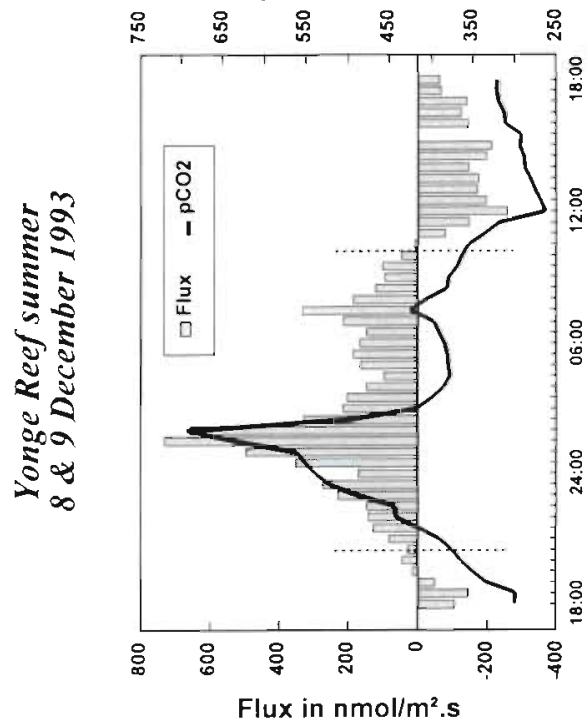

Flux in $\mathrm{nmol} / \mathrm{m}^{2}$.s $\mathrm{pCO} 2$ in $\mu \mathrm{atm}$

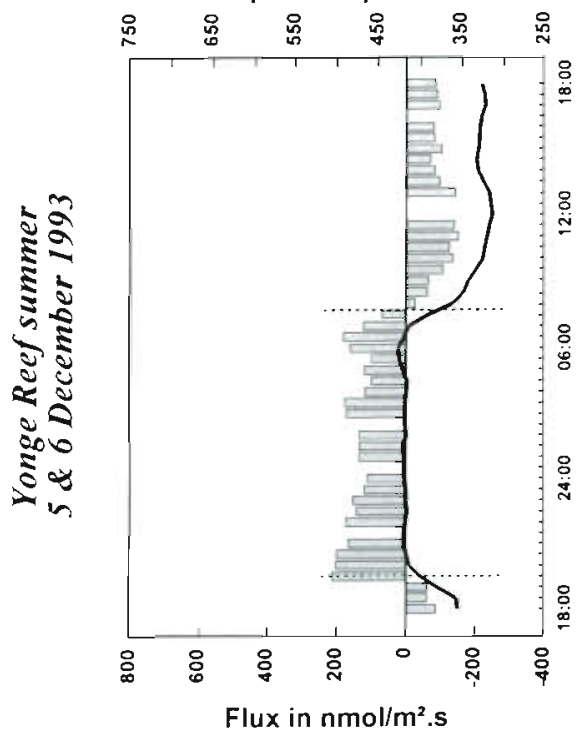

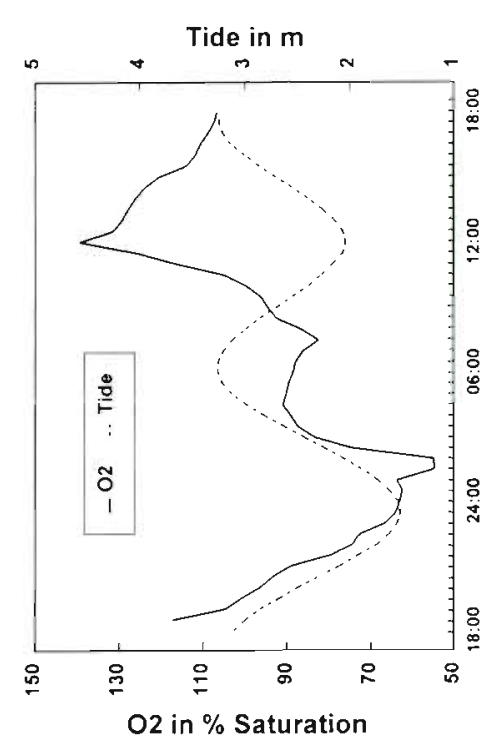

$\mathrm{O} 2$ in \% Saturation

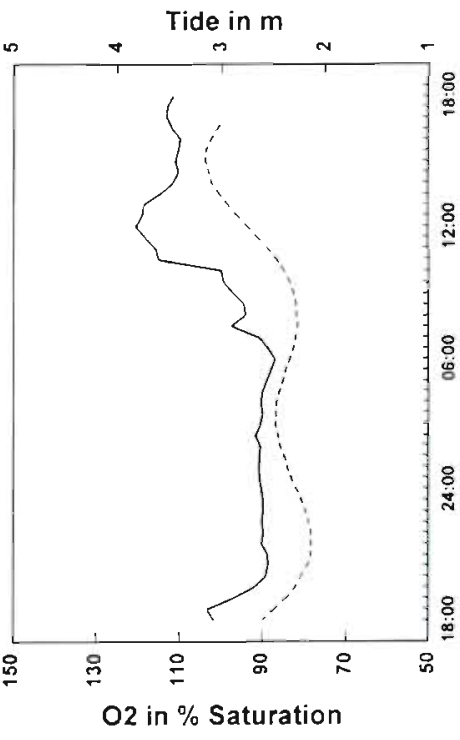

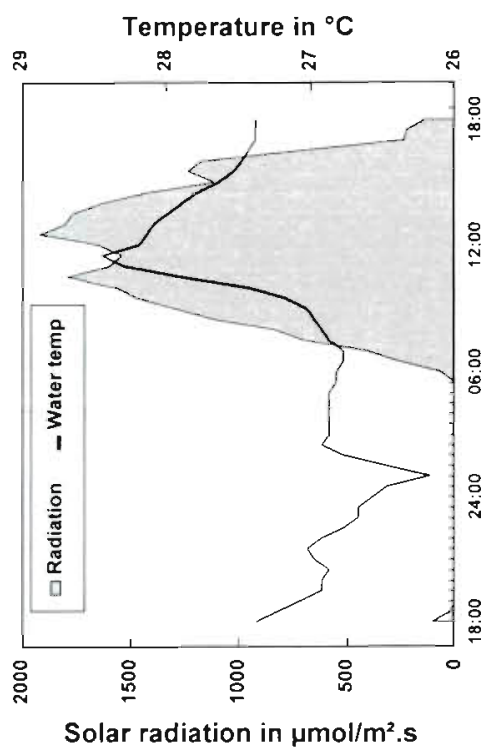

Temperature in ${ }^{\circ} \mathrm{C}$

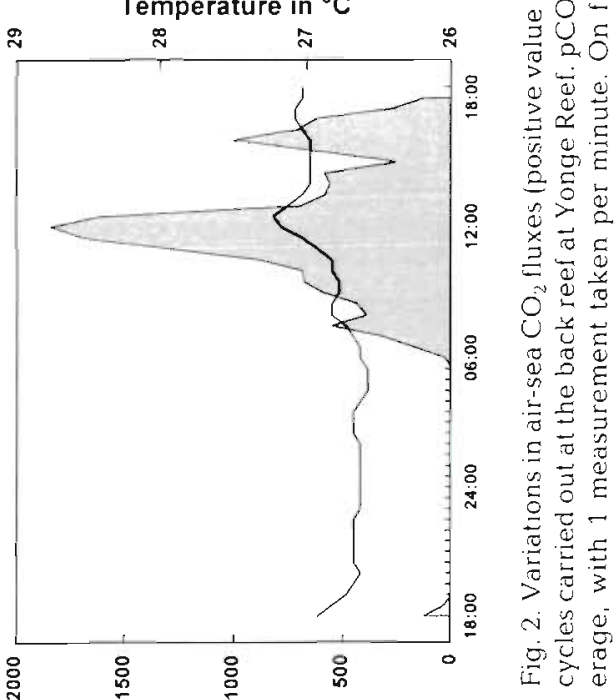

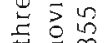

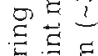

옹

政

임잉

可证

둥

\&

긍ㅎㅁ

ब

ह

$\pm \frac{\pi}{3} 3$

过

Q 
Table 2. Calculated amounts of $\mathrm{CO}_{2}$ that must be released by seawater to reach atmospheric equilibrium ( $355 \mu$ atm) at the ocean $\left(\triangle D I C_{0}\right)$ and after crossing the reef $\left(\triangle D I C_{b r}\right)$, assuming no calcification (constant $T A$ ) during equilibrium. Reef flat values show measured air-sea $\mathrm{CO}_{2}$ fluxes on the reef flat that allow calculation of the total reef effect and the atmospheric fluxes. Positive values correspond to sea-air fluxes

\begin{tabular}{|c|c|c|c|c|c|c|}
\hline & & \multirow[b]{2}{*}{$\triangle D I C_{0}$} & \multicolumn{3}{|c|}{ Atmospheric $\mathrm{C}$ budgets $\left(\mu \mathrm{mol} \mathrm{kg}^{-1}\right)$} & \multirow[b]{2}{*}{$\begin{array}{c}\text { Atmospheric potential } \\
\text { budget }\end{array}$} \\
\hline & & & Reef flat & $\begin{array}{l}- \text { Reef - } \\
\triangle D^{\prime} C_{h t}\end{array}$ & Total & \\
\hline Diel 1 & $\begin{array}{l}\text { Moorea (Winter 1992) } \\
\text { Yonge Reef (Summer 1993) }\end{array}$ & $\begin{array}{r}-20 \\
0\end{array}$ & $\begin{array}{l}-0.9 \\
+0.8\end{array}$ & $\begin{array}{r}-1 \\
+18\end{array}$ & $\begin{array}{r}-1.9 \\
+18.8\end{array}$ & $\begin{array}{l}+18.1 \\
+18.8\end{array}$ \\
\hline Diel 2 & $\begin{array}{l}\text { Moorea (Winter 1992) } \\
\text { Yonge Reef (Summer 1993) }\end{array}$ & $\begin{array}{r}-20 \\
0\end{array}$ & $\begin{array}{l}-1.6 \\
+2.0\end{array}$ & $\begin{array}{r}0 \\
+22\end{array}$ & $\begin{array}{r}-1.6 \\
+24.0\end{array}$ & $\begin{array}{l}+18.4 \\
+24.0\end{array}$ \\
\hline Diel 3 & $\begin{array}{l}\text { Moorea (Winter 1992) } \\
\text { Yonge Reef (Summer 1993) }\end{array}$ & $\begin{array}{r}-20 \\
0\end{array}$ & $\begin{array}{l}-0.8 \\
+1.0\end{array}$ & $\begin{array}{r}-10 \\
+6\end{array}$ & $\begin{array}{r}-10.8 \\
+7.0\end{array}$ & $\begin{array}{l}+9.2 \\
+7.0\end{array}$ \\
\hline
\end{tabular}

in front of the reef, clearly suggesting that the reef was as a net producer of $\mathrm{CO}_{2}$, and (3) according to the saturation level, measured daily exchanges on the reef flat range from -1.6 (Moorea) to +2.0 (Yonge Reef) $\mu \mathrm{mol} \mathrm{kg}^{-1}$. Except for diel cycles 1 and 2 at Moorea, where calculated exchanges with water after it left the reef were low, the air-sea flux occurring on the reef flat was 1 order of magnitude lower than the exchange necessary to reach equilibrium in water which had left the reef.

Data given in Table 2 are expressed in $\mu$ mol $\mathrm{kg}^{-1}$ because they describe the amount of $\mathrm{CO}_{2}$ that has to be exchanged to reach equilibrium in the observed water masses. Calculations were based upon $\mathrm{CO}_{2}$ system thermodynamics. To estimate the total effect at each site in terms of $\mathrm{CO}_{2}$ released to the atmosphere, these data have to be multiplied by the water flow that crosses the reef. The water flow was estimated to be

$44 \mathrm{~m}^{3} \mathrm{~d}^{-1}$ and $129 \mathrm{~m}^{3} \mathrm{~d}^{-1}$ per meter of reef front for Moorea and Yonge Reef respectively. Moorea and Yonge Reef were therefore (when respectively averaged) sources of $8 \mathrm{~g} \mathrm{C} \mathrm{d}^{-1}$ and $28 \mathrm{~g} \mathrm{C} \mathrm{d}^{-1}$ respectively or, by taking into account the averaged reef width, $1.8 \mathrm{mmol} \mathrm{C} \mathrm{m} \mathrm{C}^{-1}$ and $5.1 \mathrm{mmol} \mathrm{C} \mathrm{m} \mathrm{C}^{-1}$ respectively.

Finally, data presented in this paper allow a rough estimate of the global carbon dioxide emission from reef ecosystems: assuming that the potential flux is

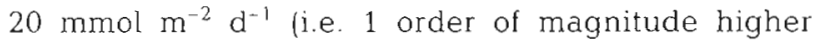
than fluxes measured in the field; see Table 2), the global $\mathrm{CO}_{2}$ flux to the atmosphere is about $0.05 \mathrm{Gt} \mathrm{C}$ $\mathrm{yr}^{-1}$. This flux represents about $1 \%$ of the present anthropogenic input and is in good agreement with the value $\left(0.02\right.$ to $\left.0.08 \mathrm{Gt} \mathrm{C} \mathrm{yr}^{-1}\right)$ computed by Ware et al. (1992).

\section{Air-sea $\mathrm{CO}_{2}$ fluxes and wind speed}

Ocean

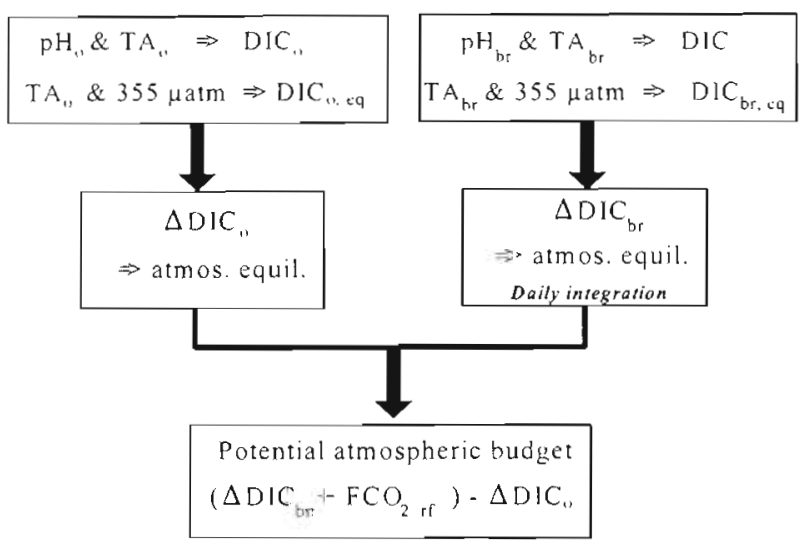

Fig. 3. Procedure used to estimate the global air-sea $\mathrm{CO}_{2}$ flux for oceanic water crossing the reef (see text). Subscripts $o$, br, eq and if refer respectively to the ocean, the back reef, the atmospheric equilibrium and the reef flat
The magnitude of the air-sea flux is a function of the exchange coefficient, $K$ (piston velocity; Eq. 1). The estimation of $K$ is complex because it depends on environmental parameters which are difficult to evaluate (e.g. wind, sea-state, bubbles, surface film; Liss 1983 , Wanninkhof 1992). Wind speed is recognized as the dominant factor that influences the exchange coefficient, and relationships that allow the calculation of $K$ as a function of wind speed have been proposed (Liss \& Merlivat 1986, Wanninkhof 1992).

Because we measured both flux and $\mathrm{pCO}_{2}$ data, we are able to derive values for $K$ at both sites. Such derivations of $K$ use Eq. (1) and take into account the salinity and temperature dependence of the $\mathrm{CO}_{2}$ solubility coefficient. It should be noted that the bell method to measure air-sea $\mathrm{CO}_{2}$ exchanges suppresses the direct wind effect on the flux such that $K$ is underestimated. On the other hand, the effect of the inner 
turbulence of a surface layer is clearly taken into account by the bell method but is difficult to reproduce in laboratory experiments, such as with the wind tunnel, which has been used to derive the Liss \& Merlivat (1986) relationship. Frankignoulle (1988) discussed results yielded at sea by the bell method over a wide range of wind speeds (from 0 to $14 \mathrm{~m} \mathrm{~s}^{-1}$ ) and sea-states and suggested that $K$-values obtained by both methods agree within $30 \%$.

Calculated $K$-values are shown versus wind speed in Fig. 4 At Yonge Reef, wind speed was 6 to $11 \mathrm{~m} \mathrm{~s}^{-1}$ and thus above the value that is characterized by a stronger influence of wind effect $\left(3.6 \mathrm{~m} \mathrm{~s}^{-1}\right.$; Liss \& Merlivat 1986). It is clear from Fig. 4 that most of our set of experimental $K$-values fall between the 2 theoretical curves.

At Moorea in winter, wind speed was most often lower than $6 \mathrm{~m} \mathrm{~s}^{-1}$ but corresponding $K$ values were higher (about $5 \times 10^{-5} \mathrm{~m} \mathrm{~s}^{-1}$ ) than those proposed by the theoretical curves. This observation can be explained by the fact that the reef flat is a turbulent system (depth $\approx 1 \mathrm{~m}$ and current $\approx 0.2 \mathrm{~m} \mathrm{~s}^{-1}$ ) and that this turbulence, independent from the wind, increases the exchange coefficient as detected by the bell method. This effect is masked in Yonge Reef due to higher wind speed, which increases the exchange coefficient. Using the coefficient obtained at low wind speed in Moorea, one can calculate that the averaged daily fluxes obtained at Yonge Reef $(2.7,6.5$ and $3.2 \mathrm{mmol} \mathrm{m}{ }^{-2} \mathrm{~d}^{-1}$; cf. Table 1) would, under similar turbulence conditions, be respectively equal to $1.9,3.5$ and $1.0 \mathrm{mmol} \mathrm{m}^{-2} \mathrm{~d}^{-1}$, i.e. about $50 \%$ of the observed values.

Finally, Eq. (1) can be used, with averaged $\mathrm{pCO}_{2}$ and calculated exchange coefficients, to estimate that 3 to $6 \mathrm{~d}$ would be needed to restore equilibrium after water crosses the reef.

Piston velocity $\left(10^{-3} \mathrm{~m} \cdot \mathrm{s}^{-1}\right)$

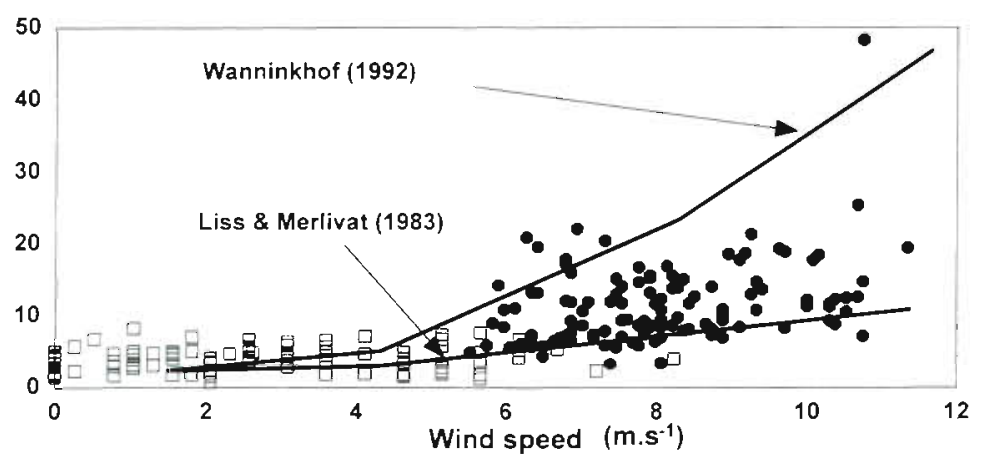

Fig. 4. Piston velocity versus wind speed obtained at Moorea in winter $(\square)$ and at Yonge Reef in summer (-). Theoretical curves are also indicated (see text)
Table 3. Regression data obtained by plotting $\ln \left(\mathrm{pCO}_{2}\right)$ versus $\ln (D I C)$ to yield the homogeneous buffer factor $\beta$ (slope; $c f$. Fig. 5 )

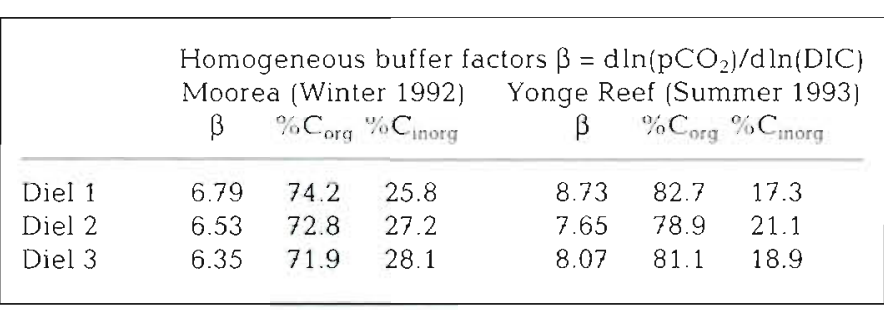

\section{Dynamics of inorganic carbon}

$\mathrm{pCO}_{2}$ displayed strong daily variations at the 2 sites investigated. These were related to metabolic processes that induce changes in the dynamics of total inorganic carbon. Numerous natural processes are liable to modify seawater $\mathrm{pCO}_{2}$ and its total inorganic carbon content (e.g. Stumm \& Morgan 1981) (1) Primary production decreases $\mathrm{pCO}_{2}$ as a result of uptake of dissolved $\mathrm{CO}_{2}$ and $\mathrm{H}_{2} \mathrm{O}^{+}$. Respiration has the opposite effect. (2) Calcification increases $\mathrm{pCO}_{2}$ as a result of chemical equilibration involved with carbonate fixation. (3) Air-sea exchange of $\mathrm{CO}_{2}$ increases or decreases dissolved $\mathrm{CO}_{2}$. (4) Increase in temperature increases $\mathrm{pCO}_{2}$ due to changes in the $\mathrm{CO}_{2}$ solubility coefficient and of the carbonic acid equilibrium constants.

Although these processes occur simultaneously, their relative intensity varies throughout the day and according to season. Consequently, the $\mathrm{CO}_{2}$ distribution at any particular time can be difficult to estimate.

The data set presented here allows estimations of the homogeneous buffer factor $\beta$ (cf. Eq. 2), the value of which highly depends on the process responsible for changes in inorgaric carbon concentration (cf

Eq. 3). Fig 5 shows that the correlation between $\ln \left(\mathrm{pCO}_{2}\right)$ and $\ln (\mathrm{DIC})$ is very high, with $\mathrm{r}^{2}$ ranging from 0.96 to 0.99 . $\beta$ values are about 6.5 and 8 at Moorea and Yonge Reef respectively (Table 3). Assuming that changes in dissolved $\mathrm{CO}_{2}$ induced by air-sea exchange are negligible compared with changes induced by organic metabolism, Eq. (3) allows for the calculation that the proportion of total carbon uptake used for organic metabolism is about $73 \%$ at Moorea and $80 \%$ at Yonge Reef. These results agree well with those obtained by Gattuso et al. (1996), who determined metabolic parameters on the reef flats (gross photosynthesis, respiration and net calcification) using a Lagrangian technique. The approach proposed here, using $\mathrm{pCO}_{2}$ and DIC dynamics 
at a single station, is an alternative method for determining the relative importance of calcification and the net production. Robertson et al. (1994) recently used this approach to study a coccolithophore bloom in the North Atlantic. Their results suggest that $50 \%$ of the uptake of inorganic carbon goes to organic metabolism in this ecosystem.

The assumption that air-sea $\mathrm{CO}_{2}$ exchanges are negligible in the above calculation can easily be justified (see also Smith \& Veeh 1989, Smith 1995). Although air-sea fluxes are quite important on the reef flat, their magnitude is low compared with metabolic parameters: the daily air-sea $\mathrm{CO}_{2}$ fluxes (ca $1 \mathrm{mmol} \mathrm{m} \mathrm{m}^{-2} \mathrm{~d}^{-1}$; see Table 1) are 2 to 3 orders of magnitude lower than gross primary production, respiration and net calcification $(-821,+730$ and $-186 \mathrm{mmol}$ $\mathrm{m}^{-2} \mathrm{~d}^{-1}$ respectively in Moorea and $-1279,+1243$ and $-253 \mathrm{mmol} \mathrm{m}^{-2} \mathrm{~d}^{-1}$ in Yonge Reef; Gattuso et al. 1996).

Fig 5 also shows that $\beta$ is constant over the entire diel cycle. In terms of $\mathrm{CO}_{2}$ chemical dynamics, this means that the amount of uptake or release of dissolved $\mathrm{CO}_{2}$ due to any process over the amount of effective carbonate ion uptake for calcification was

Moorea

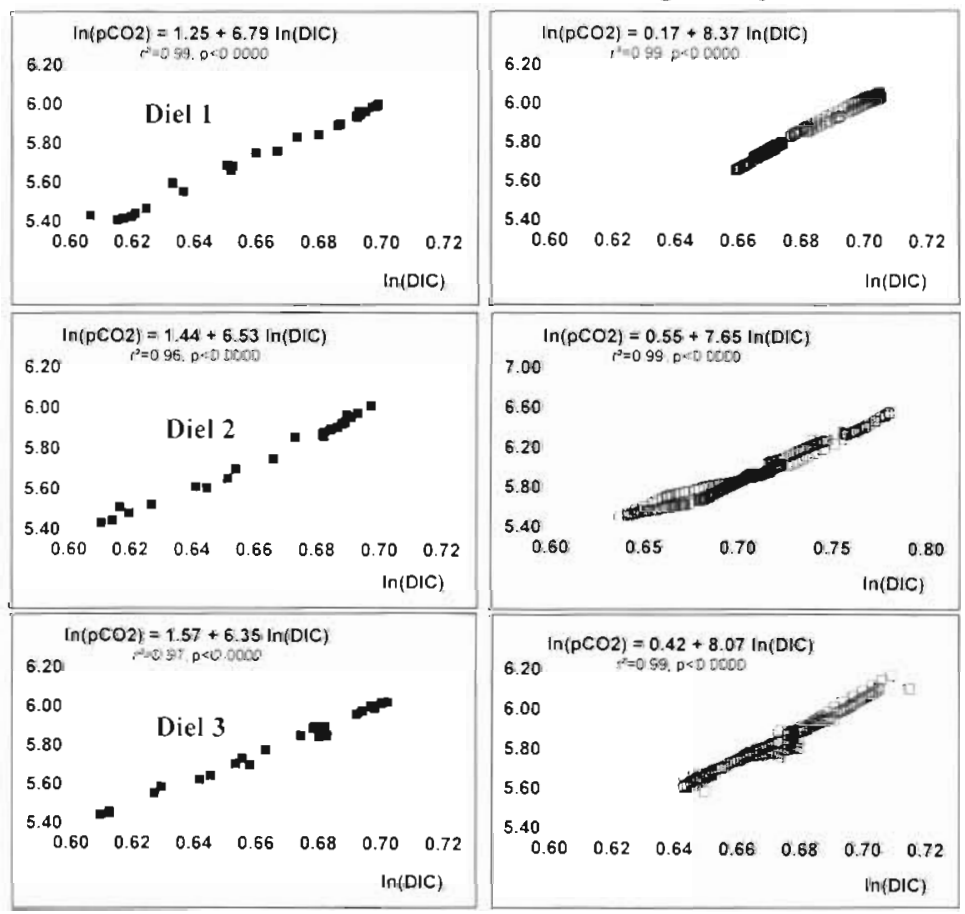

Fig. 5. Plots of $\ln \left(\mathrm{pCO}_{2}\right)$ versus $\ln (\mathrm{DIC})$ obtained during diel cycles in order to assess the homogeneous buffer factor $\beta$ (slope; see text). For the second cycle at Yonge Reef, scales were adjusted to the wider range of observed values. $\mathrm{pCO}_{2}$ data were normalized to $27^{\circ} \mathrm{C}$ as described by Copin-Montegut (1988) constant during the measurements. Since air-sea $\mathrm{CO}_{2}$ exchange is negligible compared with metabolic fluxes, the proportions of inorganic carbon for organic metabolism and inorganic metabolism are constant. Thus, the daytime ratio net photosynthesis/calcification and the nighttime ratio respiration/calcification are constant at both sites. This observation is also suggested by the Lagrangian approach and is discussed in detail, in terms of metabolic significance, by Gattuso et al. (1996).

\section{Conclusions}

Both Moorea and Yonge Reef flats were potential sources of atmospheric $\mathrm{CO}_{2}$. The overall fluxes calculated for Yonge Reef are about 4 times higher than for Moored.

As might be expected, the saturation level of oceanic water with respect to $\mathrm{CO}_{2}$ is of prime importance in calculations of the global effect of reef metabolism on the atmospheric budget for $\mathrm{CO}_{2}$. An atmospheric budget cannot be derived from observations made solely over reefs. Data obtained at Moorea in winter have shown that initial (oceanic) conditions can result in air-sea fluxes of $\mathrm{CO}_{2}$ over the reef flat whilst overall the reef indeed behaves as a net source of $\mathrm{CO}_{2}$

$\mathrm{CO}_{2}$ exchange occurring on the reef flat contributes very little to the air-sea $\mathrm{CO}_{2}$ equilibration; most of the equilibration takes place after the water mass has left the reef flat.

These results emphasise the need for further field data to assess the role of coral reefs in terms of atmospheric budget. The wide range of ecological conditions (preservation, biodiversity, photosynthesis versus calcification, etc.) encountered in these ecosystems could be responsible for substantially different conclusions. At any rate, it must be borne in mind that reef systems have a minor role in the present carbon budget (Crossland et al. 1991)

The homogeneous buffer factor $\beta$ was remarkably constant over $24 \mathrm{~h}$ at both sites and can therefore be used to estimate the percentage of the inorganic carbon uptake used for calcification. The constancy of $\beta$ over $24 \mathrm{~h}$ also suggests that calcification is proportional to net production during the day and to respiration rate at night, which is consistent with metabolic rate relations as determined by other techniques 
Acknowledgements. We thank the staffs of EPHE (Moorea) and the Australian Institute of Marine Science, as well as the captain and crew of the RV 'Lady Basten' for their help during field work. We also thank Anna Salih for technical assistance, D. J. Barnes, B. E. Chalker, S. V. Smith and 1 anonymous referee for pertinent comments on the original manuscript. This work was funded by the Fonds National de la Recherche Scientifique (Belgium), with which M.F. is a Research Associate, the Australian Institute of Marine Science (Australia), the Centre Scientifique de Monaco (Principality of Monaco), the Centre National de la Recherche Scientifique (France), the Council of Europe, the Société Nationale Elf-Aquitaine and the Programme National Récifs Coralliens (PNRCO. France). This is a contribution of PNRCO.

\section{LITERATURE CITED}

Benson BB, Krause D (1984) The concentration and isotopic fractionation of oxygen dissolved in freshwater and seawater in equilibrium with the atmosphere. Limnol Oceanogr 29:620-632

Buddemeier B (1996) Coral reefs and carbon dioxide. Science: $271.1298-1299$

Copin-Montegut C (1988) A new formula for the effect of temperature on the partial pressure of carbon dioxide in seawater. Mar Chem 25:29-37

Crossland CJ, Hatcher B, Smith SV (1991) Role of coral reefs in global ocean production. Coral Reefs 10:55-64

Culkin F (1965) The major constituents of seawater. In: Riley JP, Skirrow G (eds) Chemical oceanography, Vol 2, 2nd edn. Academic Press, London, p 121-161

Dickson AG (1993) pH buffers for seawater media based on the total hydrogen ion concentration scale. Deep Sea Res 40:107-118

Frankignoulle $\mathrm{M}$ (1988) Field measurements of air-sea $\mathrm{CO}_{2}$ exchange. Limnol Oceanogr 33:313-322

Frankignoulle $M$ (1994) A complete set of buffer factors for acid/base $\mathrm{CO}_{2}$ system in seawater $\mathrm{J}$ Mar Syst 5:111-118

Frankignoulle M, Canon C, Gattuso JP (1994) Marine calcification as a source of carbon dioxide: positive feedback of increasing atmospheric $\mathrm{CO}_{2}$. Limnol Oceanogr 39 : $458-462$

Gattuso JP, Frankignoulle M, Smith SV, Ware J, Wollast R (1996) Coral reefs and carbon dioxide. Science 271:1298

Gattuso JP, Pichon M, Delesalle B, Canon C. Frankignoulle M (1996) Carbon fluxes in coral reefs. I. Lagrangian measurement of community metabolism and resulting alr-sea $\mathrm{CO}_{2}$ disequilibrum. Mar Ecol Prog Ser 145:109-121

Gattuso JP, Pichon M, Delesalle B, Frankignoulle M (1993) Community metabolism and air-sea $\mathrm{CO}_{2}$ fluxes in a coral reef ecosystem (Moorea, French Polynesia). Mar Ecol Prog Ser 96:259-267

Goyet C, Poisson A (1989) New determination of carbonic acid dissociation constants in seawater as a function of temperature and salinity. Deep Sea Res 36:1635-1654

Hansson I (1973) A new set of acidity constants for carbonic acid and boric acid in seawater. Deep Sea Res 20:461-478

Kayanne H, Suzuki A, Saito H (1995) Diurnal changes in the partial pressure of carbon dioxide in coral reef water. Science 269:214-21.6

Kinsey DW (1983) Standards of performance in coral reef primary production and turnover. In: Barnes DJ (ed) Perspec- tives on coral reefs. Australian Institute of Marine Science, Townsville, p 209-220

Liss P (1983) Gas transfer: experiments and geochemical implications. In: Liss PS, Slinn WG (eds) Air-sea exchanges of gases and particles. NATO ASI Series, Reidel, Utrecht, p 241- 298

Liss P, Merlivat L (1986) Air-sea gas exchange rates: introduction and synthesis. In: Buat-Ménard $P(e d)$ The role of airsea exchanges in geochemical cycling. NATO ASI Series, Reidel, Utrecht, p 113-128

Mackenzie FT, Bewers JM, Charlson RJ, Hofman EE, Knauer GA, Kraft JC, Nöthig EM, Quack B, Walsh JJ, Whitfield M, Wollast $R$ (1991) What is the importance of ocean margin processes in global change? In: Mantoura RFC, Martin $\mathrm{JM}$, Wollast R (eds) Ocean margin processes in global change. Wiley \& Sons, Chichester, p 433-454

Mehrbach $\mathrm{C}$, Culberson $\mathrm{CH}$, Hawley JE, Pytkowicz RM (1973) Measurements of the apparent dissociation constants of carbonic acid in seawater at atmospheric pressure. Limnol Oceanogr 18:897-907

Perez FF, Fraga $F$ (1987) The $\mathrm{pH}$ measurements in seawater on the NBS scale. Mar Chem 21:315-327

Redfield AC, Ketchum BH, Richards FA (1963) The influence of organisms on the composition of seawater. In: Hill MN (ed) The sea, Vol 2. Wiley-Interscience, New York, p 26-77

Robertson JE, Robinson C, Turner DR, Holligan P, Watson AJ, Boyd P. Fernandez E, Finch M (1994) The impact of a coccolithophore bloom on oceanic carbon uptake in the NE Atlantic during Summer 1991. Deep Sea Res 41:297-314

Smith SV (1978) Coral reef area and the contributions of reefs to processes and resources of the world's ocean. Nature $273: 225-226$

Smith SV (1995) Reflections on the measurement and significance of carbon metabolism on coral reefs. Kansas Geological Survey Open-File Report, Lawrence, Sernes 95-96a, p 1-18

Smith SV, Veeh HH (1989) Mass balance of biogeochemically active materials (C, N, P) in a hypersaline gulf. Estuar Coast Shelf Sci 29:195-215

Stumm W, Morgan JJ (1981) Aquatic chemistry, 2nd edn. Wiley-Interscience, New York

Sundquist ET. Plummer LN (1981) Carbon dioxide in the ocean surface: the homogeneous buffer factor. Science 204:1203-1205

Tans PP, Fung [Y, Takahashi $T$ (1990) Observational constraints on the global atmospheric $\mathrm{CO}_{2}$ budget. Science $247: 1431-1438$

Wanninkhof R (1992) Relationship between wind speed and gas exchange over the ocean. J Geophys Res 97 $7373-7382$

Ware JR, Smith SV, Reaka-Kudla ML (1992) Coral reefs: sources or sinks of atmospheric $\mathrm{CO}_{2}$ ? Coral Reefs 11:127-130

Watson AJ, Robinson C, Robertson JE, Williams PJleB, Fasham JR (1991) Spatial variability in the sink for atmospheric carbon dioxide in the North Atlantic. Nature 350: 50-53

Weiss RF (1974) Carbon dioxide in water and seawater: the solubility of a non-ideal gas. Mar Chem 2:203-215

Wollast R (1991) The coastal organic carbon cycle: fluxes, sources and sinks. In: Mantoura RFC, Martin JM, Wollast $R$ (eds) Ocean margin processes in global change. Wiley \& Sons, Chichester, p 365-382

Manuscript first received: December 15, 1995

Revised version accepted: October 2, 1996 